\title{
Pengaruh PSAK 50/55 (Revisi 2014) Berbasis IFRS dan Kualitas Audit Terhadap Manajemen Laba
}

\author{
Nazarudin* \\ Akademi Perpajakan Panca Bhakti \\ Joko Suseno \\ Akademi Perpajakan Panca Bhakti
}

\begin{abstract}
The aim of this study is to analyze the effect of the implementation of the IFRS-based PSAK 50 and 55 (revised 2014) and the audit quality of earning management. Both independent variables, the implementation of IFRS-based PSAK 50/55 (Revised 2014) and the audit quality, are dummy variables. In this study, to measure the earning management this research using revenue discretionary model calculated by using conditional revenue model introduced by Stubben (2010). The sample is secondary data derived from annual financial statements at manufacturing companies listing on Indonesia Stock Exchange (BEI) in 2014-2015. The sample has been taken by purposive sampling method that follow the population criteria. The population are the manufacturing companies by 97 companies for 2 years (2014-2015) as sample. The statistical analysis have been used are multiple linear regression and t-test different test. The findings show that both the implementation of the IFRS-based PSAK 50/55 (Revised 2014) and the audit quality have had a significantly and negatively effect on the earning management practices.
\end{abstract}

Keywords: PSAK 50 and 55 (revised 2014), earning management, audit quality, manufacturing company, revenue discretionary model

\section{PENDAHULUAN}

Indonesia merupakan salah satu negara di dunia yang mulai mengadopsi IFRS karena perusahaan-perusahaan di Indonesia sudah memasuki persaingan pasar global, dengan tujuan menarik investor asing. Agar tujuan tersebut dapat terlaksana maka Standar Akuntansi Keuangan yang berlaku di Indonesia harus disesuaikan dengan standar akuntansi internasional (IFRS). Revisi demi revisi dilakukan terhadap PSAK dalam mengadopsi IFRS. Lembaga profesi akuntansi IAI (Ikatan Akuntan Indonesia) menetapkan bahwa Indonesia melakukan adopsi penuh IFRS per 1 Januari 2012.

Salah satu informasi yang ada di dalam laporan keuangan diantaranya adalah informasi mengenai laba perusahaan. Bagi investor maupun kreditor, informasi mengenai

\footnotetext{
* Korespondensi: Nazarudin, Program Studi D3 Manajemen Perpajakan, Akademi Perpajakan Panca Bhakti, Jalan Sultan Abdurrahman No. 8 Pontianak, Kalimantan Barat. Email: nazarrazali@gmail.com
} 
laba digunakan untuk melakukan evaluasi kinerja manajemen, memperkirakan earning power dan untuk meramalkan laba dimasa yang akan datang (Siallagan \& Machfoedz, 2006). Kecenderungan investor dan pihak eksternal lainnya yang hanya lebih fokus pada informasi laba, memicu manajemen melakukan perilaku menyimpang (disfuncional behaviour) berupa manajemen laba (earning management) atau manipulasi laba (earning manipulation) untuk menghasilkan laba yang dianggap normal bagi suatu perusahaan (Bartov, 1993 dalam Kusumanigtyas, 2012).

Manajemen laba ditimbulkan karena adanya asimetri informasi antara pihak principal (pemilik) dan agent (manajemen), dimana pihak manajemen mempunyai informasi yang lebih tentang kinerja dan kondisi perusahaan. Manajemen laba sering dipandang lazim bagi profesi akuntansi dan telah menjadi fenomena umum terjadi di sejumlah perusahaan. Maksud dan konsekuensi dari manajemen laba juga sering dipandang negatif, karena prinsip atau praktik dari manajemen laba seringkali mengaburkan atau menutupi fakta yang seharusnya diketahui oleh publik

Scott (2009) menjelaskan manajemen laba adalah tindakan manajer untuk melaporkan laba yang dapat memaksimalkan kepentingan pribadi atau perusahaan dengan menggunakan kebijakan akuntansi. Contoh beberapa kasus skandal pelaporan keuangan seperti Enron, Merck, World. Com dan mayoritas perusahaan yang lainnya di Amerika Serikat menyebabkan publik Amerika Serikat meragukan integritas dan kredibilitas para pelaku dunia usaha (Sulistyanto, 2008).

Salah satu kasus manajemen laba yang pernah terjadi di Indonesia yang cukup fenomenal adalah PT. Kimia Farma, Tbk yang merupakan produsen obat-obatan milik pemerintah di Indonesia. Berdasarkan hasil Badan Pengawas Pasar Modal (2002) diperoleh bukti bahwa terdapat kesalahan penyajian laporan keuangan PT. Kimia Farma Tbk, berupa kesalahan dalam penilaian persediaan barang jadi dan kesalahan dalam melakukan pencatatan penjualan, dimana dampak kesalahan tersebut mengakibatkan overstated laba pada laba bersih sebesar 32,7 Miyar untuk tahun yang berakhir 31 Desember 2001.

IFRS mulai mendapat perhatian dan menjadi suatu fenomena yang menarik di Indonesia. Revisi demi revisi dilakukan terhadap PSAK dalam mengadopsi IFRS. Dua diantaranya yaitu PSAK No.50 dan PSAK No.55, Ikatan akuntansi keuangan (IAI) pada bulan September 2006 mengeluarkan exposure draft (ED) PSAK 50 dan 55 (revisi 2006) tentang instrumen keuangan, yang merupakan adopsi dari IAS 32 dan IAS 39 yang telah diamandemen. PSAK 50 (Revisi 2014) mengatur tentang Prinsip penyajian instrumen keuangan sebagai liabilitas atau ekuitas dan saling hapus aset keuangan dan liabilitas keuangan, sedangkan PSAK 55 (Revisi 2014) mengatur tentang pengakuan dan pengukuran instrumen keuangan. PSAK 55 secara mendasar mengubah metode pengukuran dan pengakuan. Salah satu perubahan adalah pengakuan aset keuangan. PSAK 55 membagi aset keuangan menjadi empat klasifikasi yaitu; aset keuangan yang ditetapkan untuk diukur pada nilai wajar melalui laporan laba rugi, investasi dimiliki hingga jatuh 
tempo, pinjaman yang di berikan atau piutang dan aset untuk dijual. Salah satu klasifikasi aset keuangan adalah pinjaman yang diberikan atau piutang.

Diharapkan dengan adanya penyajian dan pengungkapan instrumen keuangan tersebut dapat dimengerti oleh para pengguna laporan keuangan. Perusahaan mencatat aset dan liabilitas keuangan tertentu pada nilai wajar yang mengharuskan penggunaan estimasi akuntansi. Perubahan nilai wajar aset dan liabilitas keuangan tersebut dapat mempengaruhi secara langsung laba atau rugi perusahaan, oleh karena itu PSAK tersebut sangat berpengaruh terhadap laporan keuangan perusahaan.

Penerapan Pernyataan Standar Akuntansi Keuangan (PSAK) berbasis IFRS ini merupakan salah satu upaya untuk menekan praktek manajemen laba, antara lain dengan pendekatan principles based-nya, pengetatan aturan dan pendekatan fair value dalam penyajian laporan keuangan dianggap dapat meminimalisir tingkat manajemen laba yang dilakukan oleh manajemen perusahaan. Hal ini sesuai dengan pernyataan IAI tahun 2009 yang dikutip dari Narendra (2013) yang menyebutkan bahwa IFRS dapat mempersulit tindakan manajemen laba melalui penerapan fair value dan balance sheet approach. Hal ini juga didukung oleh penelitian Cai et al. (2008) dalam Handayani (2014) mengungkapkan salah satu isu dari IASB, bahwa standar internasional bertujuan untuk menyederhanakan berbagai alternatif kebijakan akuntansi yang diperbolehkan dan diharapkan untuk membatasi pertimbangan kebijakan manajemen (management's discretion) terhadap manipulasi laba sehingga dapat meningkatkan kualitas laba.

Penelitian tentang pengaruh adopsi IFRS terhadap perubahan perilaku manajemen laba masih memiliki hasil yang bertentangan. Berbagai penelitian telah dilakukan untuk melihat pengaruh adopsi IFRS terhadap praktik manajemen laba salah satunya oleh Handayani (2014) yang menyatakan bahwa adopsi IFRS tidak berpengaruh terhadap manajemen laba akrual maupun manajemen laba riil pada perusahaan manufaktur di Indonesia. Namun, penelitian yang dilakukan oleh Narendra (2013) menyatakan bahwa adopsi IFRS berpengaruh positif terhadap manajemen laba, tetapi penurunan tingkat manajemen laba tidak terlalu signifikan. Berbeda dengan hasil penelitian Anggun (2016), temuan ini menunjukkan bahwa adopsi IFRS tidak berpengaruh terhadap manajemen laba. Hasil penelitian ini menduga bahwa hasil yang diterapkan pada perusahaan Indonesia masih dalam tahap persiapan sehingga masih belum efektif.

Selain penerapan PSAK No 50/55 (Revisi 2014) berbasis IFRS, perusahaan pun perlu meningkatkan kualitas audit. Dengan adanya fenomena aktivitas manajemen laba yang semakin tinggi, maka auditor diharuskan memiliki kualitas audit yang sangat baik dalam mendeteksi aktivitas manajemen laba. Nurina (2011) berpendapat bahwa auditor yang berkualitas mampu mendeteksi manajemen laba yang dilakukan klien, sehingga manajer akan cenderung melakukan pembatasan terhadap besarnya accrual discretionary. Menurut penelitian yang dilakukan oleh Mahdi et al. (2005) salah satu indikator kualitas audit yang dapat digunakan untuk mendeteksi manajemen laba adalah ukuran KAP. Pada ukuran KAP yang lebih besar diduga audit yang dilaksanakan lebih berkualitas karena 
adanya kecenderungan untuk lebih berhati-hati dalam melaksanakan audit termasuk menjalankan prosedur-prosedur audit yang baku dibandingkan dengan KAP yang lebih kecil.

Berdasarkan hasil penelitian terdahulu yang telah dilakukan oleh beberapa penelitian sebelumnya, masih terdapat adanya research gap atau inconsistency mengenai pengaruh penerapan PSAK berbasis IFRS dan kualitas audit. Keunikan penelitian ini dibandingkan dengan penelitian-penelitian terdahulu adalah penelitian ini menggunakan revenue discretionary model. Adapun perhitungan yang digunakan adalah dengan menggunakan conditional revenue model yang diperkenalkan oleh Stubben (2010). Penelitian-penelitian terdahulu rata-rata menggunakan discretionary accrual untuk mengukur manajemen laba yang dihitung dengan menggunakan modified jones model. Penelitian ini bertujuan untuk mengetahui pengaruh PSAK nomor 50/55 (revisi 2014) berbasis IFRS dan pengaruh kualitas audit terhadap manajemen laba perusahaan.

\section{KAJIAN LITERATUR}

\subsection{Teori Keagenan (Agency Theory)}

Sebagai dasar untuk memahami corporate governance maka digunakanlah perspektif hubungan keagenan. Jensen dan Meckling (1976) menyatakan bahwa hubungan keagenan adalah sebuah kontrak antara manajer dengan investor. Fenomena terjadinya konflik kepentingan antara pemilik dan agen karena kemungkinan agen bertindak sesuai dengan kepentingan prinsipal, sehingga memicu biaya keagenan. Sebagai agen, seorang manajer bertanggung jawab secara moral untuk mengoptimalkan keuntungan para pemilik dengan memperoleh kompensasi sesuai dengan kontrak. Dengan demikian terdapat dua kepentingan yang berbeda didalam perusahaan dimana masing-masing pihak berusaha untuk mencapai atau mempertahankan tingkat kemakmuran yang dikehendaki.

Dari sudut pandang teori keagenan di atas, dapat disimpulkan bahwa hubungan antara masyarakat dengan pemerintah adalah seperti hubungan antara prinsipal dan agen. Masyarakat adalah prinsipal dan pemerintah adalah agen. Prinsipal memberikan wewenang pengaturan kepada agen, dan memberikan sumber daya kepada agen (dalam bentuk pajak dan lain-lain) (Putri, 2013). Pada dasarnya agency theory merupakan model yang digunakan untuk memformulasikan permasalahan (conflict) antara manajemen (agent) dengan pemilik (principal). Model hubungan principal-agent diharapkan dapat memaksimumkan utilitas principal dan dapat memuaskan serta menjamin agen untuk menerima reward dari hasil aktivitas pengelolaan perusahaan. Ketika pemilik tidak dapat memonitor secara sempurna aktivitas manajemen, maka secara potensial manajemen dapat menentukan kebijakan yang mengarah pada peningkatan level kompensasinya. Peran teori keagenan dalam penelitian ini adalah untuk memahami konsep dari tata kelola perusahaan yang baik. 


\subsection{Signaling Theory}

Menurut Wolk, et al. (2001) teori sinyal menjelaskan alasan perusahaan menyajikan informasi untuk pasar modal. Alasan mengapa perusahaan mempunyai dorongan untuk memberikan informasi kepada pihak eksternal adalah karena terdapat asimetri informasi antara manajemen perusahaan dan pihak-pihak yang berkepentingan dengan informasi tersebut. Manajemen perusahaan mengetahui lebih banyak informasi mengenai perusahaan, prospek yang akan datang dari pada pihak luar (investor dan kreditor).

Informasi merupakan unsur penting bagi investor dan pelaku bisnis karena informasi pada hakekatnya menyajikan keterangan, catatan atau gambaran baik untuk keadaan masa lalu, saat ini maupun keadaan masa yang akan datang bagi kelangsungan hidup suatu perusahaan dan bagaimana efek pasarnya. Informasi yang lengkap, akurat dan tepat waktu sangat diperlukan oleh investor di pasar modal sebagai alat analisis untuk mengambil keputusan investasi. Jika pengumuman tersebut mengandung nilai positif, maka diharapkan pasar akan bereaksi pada waktu pengumuman tersebut diterima oleh pasar. Reaksi pasar ditunjukkan dengan perubahan harga saham pada waktu informasi diumumkan dan semua pelaku pasar sudah menerima informasi tersebut, dimana pelaku pasar lebih terdahulu menganalisasi informasi tersebut sebagai sinyal buruk atau sinyal baik. Apabila pengumuman informasi tersebut sebagai sinyal baik bagi investor, maka terjadi perubahan dalam harga saham, dimana harga saham menjadi naik (Nitria, 2013).

Pengumuman informasi akuntansi memberikan sinyal bahwa perusahaan mempunyai prospek baik dimasa mendatang sehingga investor tertarik untuk melakukan perdagangan saham dengan demikian pasar akan bereaksi yang tercermin melalui perubahan dalam harga saham. Dengan demikian hubungan antara publikasi informasi baik laporan keuangan, kondisi keuangan terhadap fluktuasi harga saham dapat dilihat dalam efisien pasar. Efisiensi pasar merupakan konsep dasar yang bisa membantu kita memahami bagaimana sebenarnya mekanisme harga yang terjadi di pasar modal.

\subsection{Teori Akuntansi Positif}

Teori akuntansi positif atau yang lebih sering dikenal dengan istilah asingnya positif accounting theory telah banyak digunakan dan menjadi dasar dalam melandasi penelitian dibidang akuntansi. Istilah "positif" merujuk pada sebuah teori yang berusaha untuk membuat prediksi yang baik dari peristiwa di dunia nyata. Teori akuntansi positif memiliki kaitan dengan suatu prediksi tindakan sebagaimana pilihan atas kebijakan akuntansi oleh manajer perusahaan dan bagaimana manajer akan merespon terhadap standar akuntansi baru yang diusulkan (Scott, 2003).

Teori akuntansi positif mengambil sudut pandang bahwa perusahaan mengorganisasikan diri mereka dengan cara yang paling efisien, sehingga dapat memaksimalkan prospek perusahaan untuk bisa bertahan hidup. Watts dan Zimmerman 
(1986), merumuskan hipotesis teori akuntansi dalam bentuk "opportunistik" dan sekaligus dapat dijadikan sebagai dasar dalam pemahaman mengenai tindakan manajemen laba, diantaranya yaitu hipotesis rencana bonus, hipotesis perjanjian utang dan hipotesis biaya proses politik. Dengan demikian, peran teori akuntansi positif dalam penelitian ini adalah untuk menjelaskan hubungan antara kebijakan akuntansi dengan manajemen laba.

\subsection{Manajemen laba}

Manajemen laba adalah campur tangan manajemen dalam proses pelaporan keuangan eksternal dengan tujuan untuk menguntungkan dirinya sendiri. Manajemen laba merupakan satu faktor yang dapat mengurangi kredibilitas laporan keuangan. Menurut Scott (2009) manajemen laba adalah tindakan manajer untuk melaporkan laba yang dapat memaksimalkan kepentingan pribadi atau perusahaan dengan menggunakan kebijakan metode akuntansi. Manajemen laba merupakan sebuah tindakan yang secara sengaja dilakukan untuk mengubah informasi dalam laporan keuangan suatu perusahaan dengan tujuan untuk menyesatkan investor dan untuk mendapatkan keuntungan dari kontrak yang telah disepakati (Watts dan Zimmerman, 1990).

Dari beberapa definisi yang dijelaskan di atas dapat dikatakan bahwa manajemen laba merupakan usaha pihak manajemen yang disengaja untuk memanipulasi laporan keuangan dalam batasan yang dibolehkan oleh prinsip-prinsip akuntansi dengan tujuan untuk memberikan informasi yang menyesatkan para pengguna laporan keuangan bagi keuntungan pihak manajer. Selain itu manajemen laba dianggap sebagai tindakan penurunan kualitas laporan keuangan.

\subsection{Pola-Pola Manajemen Laba}

Pola manajemen laba menurut Scott (2012) dapat dilakukan dengan cara taking a bath, income minimization, income maximization dan Income smoothing. Taking a bath adalah pola manajemen laba yang dilakukan dengan cara menjadikan laba perusahaan pada periode berjalan menjadi sangat ekstrim rendah (bahkan rugi) atau sangat ekstrim tinggi dibandingkan dengan laba pada periode sebelumnya atau sesudahnya. Taking a bath terjadi selama periode adanya tekanan organisasi atau pada saat terjadinya reorganisasi seperti pergantian CEO baru.

Income minimization adalah pola manajemen laba yang dilakukan dengan cara menjadikan laba pada laporan keuangan periode berjalan lebih rendah dari pada laba sesungguhnya. Income minimization dilakukan pada saat profitabilitas perusahaan sangat tinggi dengan maksud agar tidak mendapat perhatian secara politis. Kebijakan yang diambil dapat berupa penghapusan atas barang modal aktiva tak berwujud, pembebanan pengeluaran iklan, pengeluaran $R \& D$ dan lainnya. Sedangkan, maksimisasi laba (income maximization) adalah pola manajemen laba yang dilakukan dengan cara menjadikan laba 
pada laporan keuangan periode berjalan lebih tinggi dari pada laba sesungguhnya. Income maximization dilakukan dengan cara mempercepat pencatatan pendapat, menunda biaya dan memindahkan biaya untuk periode lain.

Akhirnya, Income smoothing atau perataan laba merupakan salah satu bentuk manajemen laba yang dilakukan dengan cara membuat laba akuntansi relatif konsisten (rata atau smooth) dari ke periode. Dalam hal ini pihak manajemen dengan sengaja menurunkan atau meningkatkan laba untuk mengurangi gejolak dalam pelaporan laba sehingga perusahaan terlihat stabil atau tidak berisiko tinggi.

\subsection{Conditional Revenue Model}

Adanya beberapa kelemahan pada model akrual modified Jones model yang selama ini umum digunakan oleh para peneliti untuk mengukur manajemen laba (earning management), yaitu (1) estimasi cross-sectional yang secara implisit mengasumsikan bahwa perusahaan dalam industri yang sama menghasilkan proses akrual yang sama. (2) model akrual tidak menyediakan informasi untuk komponen mengelola laba perusahaan dimana model akrual tidak membedakan peningkatan diskresioner pada laba melalui pendapatan atau komponen beban (Stubben, 2010).

Kelemahan-kelemahan tersebutlah yang akhirnya mendorong Stubben untuk memperkenalkan model baru yang dikenal sebagai Conditional revenue model yang mengunakan komponen utama pendapatan yaitu piutang untuk memprediksi manajemen laba. Piutang yang tidak normal, tinggi atau rendah mengindikasikan adanya manajemen pendapatan (Stubben, 2010).

Ukuran perusahaan (firm size) merupakan proksi dari kekuatan finansial. Ukuran dan umur perusahaan merupakan proksi untuk tahap perusahaan dalam business cycle. Sebagai proksi dari kinerja operasional dari perbandingan perusahaan dengan perusahaan kompetitor, digunakan industry-median-adjusted growth rate in revenue dan industrymedian-adjusted gross margin (Stubben, 2010).

Conditional revenue model ini lebih menekankan pada banyak aspek yang mempengaruhi pendapatan diskresioner. Aspek tersebut meliputi ukuran perusahaan (size), umur perusahaan (age) dan laba kotor (gross revenue margin) yang diduga bisa digunakan untuk mendeteksi manajemen laba akrual mengenai kebijakan manajemen yang dapat menentukan atau mengambil keputusan dalam pemberian kredit yang berhubungan dengan piutang. Ketika pendapatan mengalami kenaikan maka dapat disertai dengan kenaikan piutang. Oleh karena itu, model conditional revenue dari Stubben (2010) ini menggunakan piutang akrual daripada akrual agregat sebagai fungsi dari perubahan pendapatan. Sebagai komponen akrual utama, piutang memiliki hubungan empiris yang kuat dan hubungan konseptual langsung pada pendapatan (Asward \& Lina, 2015). 
Bentuk manajemen pendapatan yang paling umum dilakukan oleh perusahaan menurut Stubben (2010) adalah pengakuan pendapatan lebih awal (premature revenue recognition). Apabila perusahaan mengakui pendapatan lebih awal, maka akan berdampak langsung pada pendapatan itu sendiri dan piutang, misalnya perusahaan mengakui dan mencatat pendapatan periode yang akan datang atau yang belum terealisasi ke periode berjalan, maka akan berdampak pada meningkatnya pendapatan dan piutang pada periode berjalan menjadi lebih besar daripada pendapatan yang sesungguhnya. Manajemen perusahaan dapat memilih beberapa kebijakan yang dapat menaikkan laba dengan mengakui pendapatan yang sebenarnya belum terealisasi seperti channel stuffing dan bill and hold sales (Stubben, 2010). Channel stuffing merupakan cara manajemen untuk menghindari pelaporan kerugian dengan melakukan kelonggaran terhadap kebijakan kredit perusahaan Tung, dkk (2008) dalam Ferdiansyah (2014). Melakukan hal ini mempunyai banyak risiko seperti barang menjadi tidak laku karena pihak distributor atau konsumen mengembalikan barang dagangan. Sedangkan bill and hold sales terjadi ketika hak kepemilikan sudah berpindah dan pembayaran telah diterima namun penjual masih memiliki produk atau produk masih ditangan penjual (Nur'aini, 2012).

\subsection{New Institutional Theory}

New Institutional Theory (NIT) merupakan teori sosiologi mengenai organisasi. Dalam teori ini dijelaskan bahwa perkembangan mengenai organisasi bukan hanya semata-mata proses teknis yang akhirnya berorientasi pada faktor efisiensi, tetapi lebih menitikberatkan kepada konsekuensi langsung dari motivasi dan rasionalitas yang ada dalam diri pelaku organisasi tersebut. Tujuan dari rasionalitas dan motivasi ini adalah agar organisasi memperoleh legitimasi dari pihak-pihak yang berkepentingan (Kurniawati, 2014).

Teori institutional pada sebuah organisasi memiliki pandangan yang kompleks tentang sebuah organisasi itu sendiri. Sebuah organisasi biasanya terbentuk ke dalam struktur formal yang terdiri dari berbagai prosedur, proses dan aturan yang rasional (termasuk sistem akuntansi formal). Fitur tersebut juga mencakup hal-hal seperti otorisasi dan prosedur pengambilan keputusan yang jelas, kebijakan personil, teknik-teknik pengukuran, pengawasan dan pengendalian kinerja organisasi, pernyataan misi dan sasaran organisasi, penggunaan dokumen tertulis untuk mencatat aktivitas organisasi, peramalan ekonometrik dan lain sebagainya (Carruthers, 1995 dalam Amirya, Djamhuri dan Ludigdo, 2012).

DiMaggio \& Powell (1983) dalam Zahra (2013) mengatakan bahwa, organisasi akan berupaya untuk menyesuaikan diri atau isomorphic (sama dalam tampilan tetapi berbeda didalamnya) akibat tekanan dari luar jika ingin bertahan hidup. Ada tiga proses bagaimana organisasi dapat menyesuaikan diri yaitu: 
a. Coersive isomorphism yaitu proses penyesuaian menuju kesamaan dengan "pemaksaan". Tekanan bisa datang dari pengaruh politik dan permasalahan legitimasi. Misalnya tekanan muncul karena isue global, terkait penggunaan standar internasional dalam pelaporan keuangan oleh perusahaan-perusahaan yang sudah go public. Perusahaan go public yang sahamnya sebagian dimiliki oleh asing atau institusi mendapatkan tekanan untuk segera melakukan penyesuaian standar pelaporan demi menuju kesamaan standar pelaporan.

b. Mimetic isomorphism yaitu proses di mana organisasi meniru organisasi lain yang berhasil dalam satu bidang, meskipun organisasi peniru tidak tahu persis mengapa mereka meniru, bukan karena dorongan supaya lebih efisisen. Misalnya tekanan untuk mengadopsi standar akuntansi berbasis IFRS, dimana perusahaan harus mengeluarkan biaya yang lebih besar terkait pengadopsian standar IFRS tersebut.

c. Normative isomorphism sering diasosiasikan dengan profesionalisasi dan menangkap tekanan normatif yang muncul di bidang tertentu. Tekanan normatif tersebut bisa muncul dari kekuatan hukum atau intervensi pemerintah dan investor, misalnya investor yang memiliki saham terbesar di perusahaan memiliki keleluasaan dalam memilih/menentukan standar akuntansi yang akan digunakan sebagai standar dalam pelaporan keuangan perusahaan.

Teori institusional, relevan untuk riset ini karena produk dari praktik akuntansi adalah laporan keuangan yang dapat digunakan sebagai dasar untuk melakukan legitimasi aktivitas organisasi. Mezias (1990) dalam Kurniawati (2014) memberikan pendapat yang berkaitan dengan kegunaan teori institusional dalam memahami praktik pelaporan keuangan, yaitu praktik pelaporan keuangan bersifat rutin dan melibatkan kepentingan dari berbagai pihak antara lain profesi akuntansi, individu dalam organisasi dan lembaga regulator. Oleh karena itu, dapat diambil kesimpulan bahwa teori institusional dapat digunakan untuk memahami mengapa penerapan PSAK berbasis IFRS sangat penting untuk diterapkan dalam perusahaan, salah satunya adalah untuk mendapatkan legitimasi dari lingkungan sekitar tempat perusahaan berada.

\subsection{IFRS dan Kualitas Akuntansi}

Adanya adopsi IFRS oleh seluruh negara di dunia, akan berpengaruh dan berhubungan erat dengan kualitas akuntansinya. Adanya keterbatasan alternatif dapat meningkatkan kualitas akuntansi dan kebijakan opportunistic manajemen terbatas dalam menentukan jumlah kualitas akuntansi (Asbaugh dan Pincus, 2001) dalam Kurniawati (2014). Jumlah kualitas akuntansi lebih baik jika dicerminkan oleh keadaan ekonomi yang mendasari perusahaan, hasil dari penerapan principles-based standard atau pengukuran akuntansi yang digunakan. Hal ini semuanya dapat meningkatkan kualitas akuntansi karena menyediakan informasi untuk investor dalam kegiatan mengambil keputusan investasi. Namun fleksibilitas dalam principles-based standard dapat memberikan 
kesempatan yang lebih besar untuk melakukan manajemen laba, sehingga dapat mengurangi kualitas akuntansi. Fleksibilitas ini, telah lama menjadi perhatian dalam peraturan pasar saham, khususnya dalam konteks internasional (e.g. Breeden, 1994 dalam Kurniawati, 2014).

Kualitas akuntansi bertambah karena perubahan sistem pelaporan keuangan yang dilakukan secara kontemporer dan dengan adanya perusahaan yang menerapkan PSAK berbasis IFRS dimana penyelenggaraannya dilakukan secara teliti. Tetapi pelaksanan IFRS yang lemah dapat menghasilkan standar yang terbatas, dengan demikian keefektifannya juga terbatas (Barth, 2008) dalam Kurniawati (2014).

\subsection{Kualitas Audit}

Secara umum audit adalah suatu proses sistematik untuk memperoleh dan mengevaluasi bukti secara objektif mengenai pernyataan tentang kejadian ekonomi, dengan tujuan untuk menetapkan tingkat kesesuaian antara pernyataan tersebut dengan kriteria yang telah ditetapkan (Mulyadi, 2002). Meutia (2004) mendefinisikan audit sebagai suatu proses untuk mengurangi ketidakselarasan informasi yang terdapat antara manajer dan para pemegang saham dengan menggunakan pihak luar untuk memberikan pengesahan terhadap laporan keuangan.

Watts dan Zimmerman, DeAngelo dalam Rusmin (2010) menyatakan bahwa kualitas auditor tergantung pada relevansi laporan auditor dalam memeriksa hubungan kontraktual dan dalam melaporkan pelanggaran. Temuan pelanggaran mengukur kualitas audit berkenaan dengan pengetahuan dan kemampuan auditor. Sedangkan pelaporan pelanggaran tergantung kepada dorongan auditor untuk mengungkapkan pelanggaran tersebut. Dorongan ini akan tergantung kepada independensi auditor tersebut (Meutia, 2004).

Praktik manajemen laba merupakan salah satu masalah keagenan yang terjadi serta adanya asimetri informasi karena adanya pemisahan antara pemegang saham dengan manajemen perusahan. Kehadiran PSAK berbasis IFRS diharapkan dapat mengurangi terjadinya kasus manipulasi terhadap manajemen laba (Earnings Management), sehingga pelaporan keuangan perusahaan bisa dimengerti oleh pasar dunia (global market). Oleh karena itu, dilakukan sebuah penelitian lebih lanjut untuk menguji apakah penerapan PSAK No 50 dan 55 berbasis IFRS (Revisi 2014) berpengaruh terhadap manajemen laba.

Dalam penelitian ini model kerangka pemikiran digambarkan sebagai berikut: 


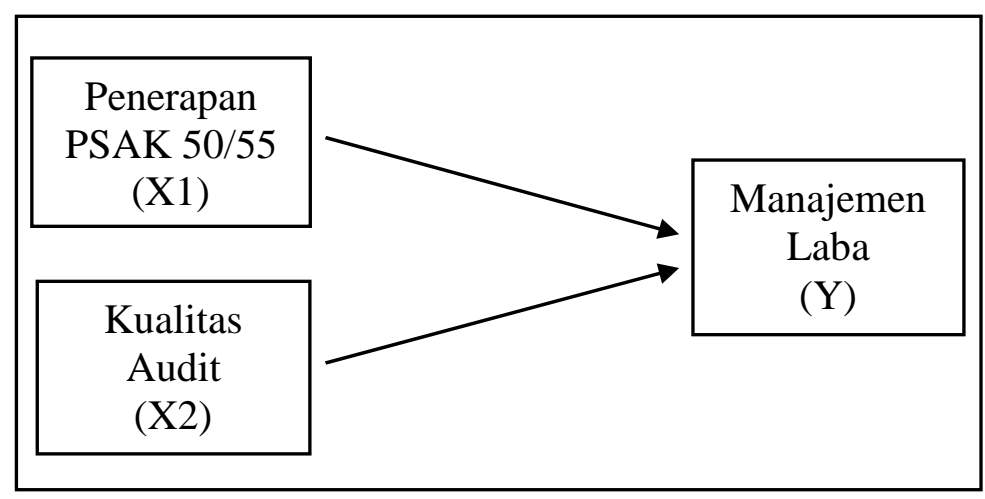

Gambar 1. Model Kerangka Pemikiran

\subsection{Pengaruh PSAK 50/55 (Revisi 2014) berbasis IFRS terhadap manajemen laba}

PSAK berbasis IFRS menggunakan pengukuran berdasarkan nilai wajar, dimana dengan menggunakan nilai wajar tersebut diharapkan pos-pos aset dan liabilitas yang dimiliki perusahaan lebih mencerminkan nilai yang sebenarnya pada saat tanggal laporan keuangan, sehingga diharapkan akan mengurangi manajemen laba yang dilakukan oleh manajemen.

IFRS dengan pendekatan principled based-nya dianggap dapat meminimalisir tingkat manajemen laba yang dilakukan oleh manajemen dengan pengetatan aturan dan pendekatan fair value dalam penyajian laporan keuangannya (Narendra, 2013). Ewert dan Wagenhof (2005) dalam Eka Purnamasari (2014) menyatakan bahwa standar akuntansi yang semakin ketat dapat menurunkan manajemen laba dan meningkatkan kualitas pelaporan keuangan. Hasil penelitian yang dilakukan oleh Zeghal dkk (2011), Barth dkk (2008), Daske dkk (2008) dalam Papeke (2015) menyatakan bahwa adopsi IFRS dapat menurunkan level manajemen laba. Kurniawati (2014) menyatakan bahwa adanya pengaruh adopsi IFRS terhadap manajemen laba, dimana manajemen laba menjadi lebih rendah setelah adopsi IFRS. Rohaeni \& Aryati (2012) dalam Papeke (2015) mengungkapkan bahwa IFRS berpengaruh negatif terhadap perilaku manajemen laba. Penelitian juga dilakukan Intan Tiara (2014) yang menyatakan bahwa hasil penelitiannya menunjukkan bahwa Penerapan PSAK 50 dan 55 (revisi 2006) tidak berpengaruh secara signifikan terhadap manajemen laba. Berdasarkan argumen-argumen tersebut maka hipotesa yang diajukan adalah:

$H_{l}$ : Penerapan PSAK berbasis IFRS berpengaruh negatif terhadap manajemen laba perusahaan. 


\subsection{Pengaruh Kualitas Audit terhadap manajemen laba.}

Auditor big four merupakan auditor yang memiliki keahlian dan reputasi yang tinggi dibanding dengan auditor non big four. Hal ini disebabkan auditor dalam kelompok KAP big four cenderung memiliki auditor yang lebih berpengalaman yang pada gilirannya memiliki kemampuan dalam membatasi besarnya manajemen laba suatu perusahaan. Jika auditor ini tidak dapat mempertahankan reputasinya, maka akan menimbulkan skeptisisme masyarakat mengenai ketidakmampuan perilaku auditor dalam berhadapan dengan klien yang dipersepsikan gagal menjalankan perannya sebagai auditor.

Penelitian yang dilakukan oleh Rusmin (2010) menunjukkan bahwa discretionary accruals yang merupakan proksi manajemen laba perusahaan yang diaudit oleh auditor big four lebih rendah dibandingkan yang diaudit oleh auditor non-big four. Penelitian serupa dilakukan Gerayli dkk (2011) yang membuktikan bahwa perusahaan yang diaudit oleh auditor big four menggunakan lebih sedikit manajemen laba. Penelitian-penelitian tersebut menunjukkan bahwa auditor Big four memiliki kemampuan untuk mendeteksi adanya praktek manajemen laba di dalam suatu perusahaan.

Dari penelitian di atas dapat disimpulkan bahwa auditor big four lebih memiliki kemampuan dalam mendeteksi adanya praktik manajemen laba dibandingkan dengan auditor non big four. Berdasarkan hal tersebut maka hipotesis yang diajukan dalam penelitian ini adalah sebagai berikut :

$H_{2}$ : Perusahaan yang diaudit oleh auditor big four lebih rendah melakukan praktek manajemen laba dibandingkan perusahaan yang diaudit oleh auditor non big four.

\section{METODE PENELITIAN}

\subsection{Populasi dan Sampel Penelitian}

Populasi penelitian ini adalah seluruh perusahaan manufaktur yang terdaftar di Bursa Efek Indonesia (BEI) selama perioda 2014-2015 (2 tahun buku). Teknik pengambilan sampel dilakukan secara purposive sampling dengan tujuan untuk mendapatkan sampel yang representatif sesuai dengan kriteria yang ditentukan. Adapun kriteria yang digunakan untuk pemilihan sampel adalah sebagai berikut:

1. Perusahaan manufaktur yang terdaftar di BEI dan mempublikasikan annual report secara konsisten dan lengkap dari tahun 2014 sampai dengan 2015. Untuk menghindari adanya bias, maka tahun 2014 dipilih sebagai awal tahun periode penelitian karena merupakan masa sebelum pengimplementasian fase 2 (dua) PSAK berbasis IFRS 2015 untuk perusahaan go public yang berlaku efektif per 1 Januari 2015.

2. Periode laporan keuangan berakhir setiap 31 Desember.

3. Perusahaan manufaktur tidak de-listing, tidak melakukan merger, akuisisi, dan perubahan usaha lainnya (divestitures) selama tahun 2014-2015.

4. Laporan keuangan menggunakan mata uang Indonesia (Rupiah). 
5. Laporan keuangan audited tahun 2014 dan 2015.

Berdasarkan kriteria-kriteria di atas, jumlah sampel yang digunakan dalam penelitian ini sebanyak 194 perusahaan.

\subsection{Variabel Dependen}

Variabel dependen dalam penelitian ini adalah manajemen laba, yang diukur menggunakan revenue discretionary model yang dihitung dengan menggunakan conditional revenue model yang diperkenalkan oleh Stubben (2010). Berikut merupakan formula dari conditional revenue model (Stubben, 2010 : 701):

di mana:

$$
\begin{aligned}
& \Delta \mathrm{AR}_{\text {it }}=\alpha+\beta_{1} \Delta \mathrm{R}_{\text {it }}+\left(\beta_{2} \Delta \mathrm{R}_{\text {it }} \times \text { SIZE }\right)+\left(\beta_{3} \Delta \mathrm{R}_{\text {it }} \times \mathrm{AGE}_{\mathrm{it}}\right)+\left(\beta_{4} \Delta \mathrm{R}_{\mathrm{it}} \mathrm{x} \text { AGE_SQ } \mathrm{Ait}\right)+ \\
& \left(\beta_{5} \Delta R_{\text {it }} \times \text { GRR_P } \mathrm{P}_{\text {it }}\right)+\left(\beta_{6} \Delta \mathrm{R}_{\text {it }} \times \mathrm{GRR} \mathrm{N}_{\mathrm{it}}\right)+\left(\beta_{7} \Delta \mathrm{R}_{\mathrm{it}} \mathrm{x} \mathrm{GRM}_{\mathrm{it}}\right)+\left(\beta_{8} \Delta \mathrm{R}_{\mathrm{it}}+\right. \\
& \text { GRM_SQ } \left.Q_{i t}\right)+\varepsilon_{\text {it }}
\end{aligned}
$$

AARit = Annual change in accounts receivable for firm $i$ in year $t$.

ARit $=$ Annual change in revenue for firm $i$ in year $t$.

$S_{\text {SIZE }} \quad=$ Natural log of total assets at end offiscal year for firm $i$ in year $t$

AGEit $\quad=$ Natural log of the firm $i$ 's age in years at year $t$.

$A G E_{-} S Q_{i t} \quad=$ Square root of the natural log of the firm $i$ 's age in year $t$.

GRR_Pit = industry-median-adjusted revenue growth (= 0 if negative)

$G R R \_N_{i t} \quad=$ industry-median-adjusted revenue growth (= 0 if positif)

GRMit = Margin kotor yang disesuaikan pada akhir tahun fiskal (industry medianadjusted gross margin at end offiscal year)

GRM_SQit = Square root of the industry-median-adjusted gross margin at end of fiscal year. (Kuadrat dari variabel/ square of variable GRM).

Sit $=$ Firm $i$ 's discretionary revenues in year $t$.

Rumusnya adalah:

1. Perubahan piutang berdasarkan model revenue dari Stubben (2010), diperoleh dari: AARit $=$ piutang tahun $\mathrm{t}-$ piutang tahun $\mathrm{t}-\mathrm{i}$

Piutang tahun $\mathrm{t}$

2. Perubahan pendapatan berdasarkan model revenue dari Stubben (2010), diperoleh dari: ARit $=$ pendapatan tahun $\mathrm{t}-$ pendapatan tahun $\mathrm{t}-1$

Rata-rata total aset

3. Size merupakan ukuran perusahaan yang diperoleh melalui natural log ( $\mathrm{Ln})$ dari total aset. Menggunakan natural log (Ln), dimaksudkan agar nilai variabel bisa disederhanakan tanpa mengubah proporsi dari nilai asal yang sebenarnya, karena jika total aset langsung digunakan begitu saja, maka nilai variabel akan sangat besar, bisa mencapai milyaran bahkan triliunan. Secara matematis ukuran perusahaan (Size) dapat dirumuskan: Size $_{i t}=$ Ln of Total Asset ${ }_{i t}$ (Nur'aini, 2012)

4. Age merupakan umur perusahaan yang diperoleh dengan menatural log-kan umur 
perusahaan (Nur'aini, 2012).

5. Age square (Age_SQ) diperoleh dengan mengkuadratkan hasil dari natural log umur perusahaan (Nur'aini, 2012).

6. Growth Rate in Revenue (GRR) dalam penelitian ini dihitung dengan rumus sebagai berikut:

$$
\text { GRR }=\text { pendapatan tahun } \mathrm{t}-\text { pendapatan tahun } \mathrm{t}-1
$$

Pendapatan tahun $\mathrm{t}-1$

Growth Rate in Revenue (GRR), terdiri dari GRR_P dan GRR_N. Untuk GRR_P, jika GRR bernilai negatif maka GRR_P sama dengan 0 sedangkan untuk GRR_N, jika GRR bernilai positif maka GRR_N sama dengan 0. (Nur'aini, 2012)

7. Gross Margin (GRM), dalam penelitian ini dihitung dengan rumus sebagai berikut:

$\mathrm{GRM}=$ pendapatan - harga pokok penjualan

Pendapatan

Sedangkan untuk memperoleh Gross Margin square (GRM_SQ) hanya dengan mengkuadratkan GRM (Nur'aini, 2012).

\subsection{Variabel Independen}

Terdapat dua variabel independen yang diajukan dalam penelitian ini, yaitu PSAK 50/55 (revisi 2014) berbasis IFRS dan kualtias audit. PSAK 50 (Revisi 2014) mengatur tentang prinsip penyajian instrumen keuangan sebagai liabilitas atau ekuitas dan saling hapus aset keuangan dan liabilitas keuangan, sedangkan PSAK 55 (Revisi 2014) mengatur tentang pengakuan dan dan penyajian Instrumen keuangan. PSAK 55 secara mendasar mengubah metode pengukuran dan pengakuan. Penerapan PSAK berbasiskan IFRS nomor 50/55 (revisi 2014) diukur dengan variabel dummy, karena melihat ada tidaknya penerapan PSAK No 50/55 berbasis IFRS. Apabila perusahaan menerapkannya maka diberi nilai 1, jika perusahaan tidak menerapkan maka diberi nilai 0

Kualitas auditor sangat menentukan kredibilitas laporan keuangan. Kualitas audit dalam penelitian ini diukur melalui ukuran KAP tempat auditor tersebut bekerja, yang dibedakan menjadi KAP Big Four dan KAP Non-Big Four. KAP big four adalah KAP yang memiliki keahlian dan reputasi tinggi dibanding dengan KAP non big four. Kantor Akuntan Publik yang termasuk dalam kelompok big four adalah:

a. KAP Tanudiredja, Wibisana \& Rekan, yang berafiliasi dengan Pricewaterhouse Coopers (PWC)

b. KAP Purwantono, Suherman \& Surja, yang berfiliasi dengan Ernst \& Young (E\&Y)

c. KAP Osman Bing Satrio \& Rekan, berafiliasi dengan Delloite Touche Thomatsu (DTT);

d. KAP Siddharta \& Widjaja, berafiliasi dengan Klynveld Peat Marwick Goerdeler (KPMG).

Ukuran KAP diukur dengan skala nominal melalui variabel dummy. Angka 1 digunakan 
untuk mewakili perusahaan yang diaudit oleh KAP Big Four dan angka digunakan untuk mewakili perusahaan yang tidak diaudit oleh KAP Non-Big Four.

\section{HASIL PENELITIAN DAN PEMBAHASAN}

\subsection{Analisis Statistik Deskriptif}

Hasil analisis statistik deskriptif dalam penelitian ini adalah sebagai berikut:

Tabel 1 Analisis Statistik Deskriptif

\begin{tabular}{lcrrrr}
\hline & N & Minimum & Maximum & Mean & Std. Deviation \\
\hline KA & 171 &, 0000 & 1,0000 &, 350877 &, 4786462 \\
SAK & 171 &, 0000 & 1,0000 &, 888889 &, 3151926 \\
EM & 171 &,- 6912 &, 5527 &, 027106 &, 1879734 \\
Valid N & 171 & & & & \\
\hline
\end{tabular}

Berdasarkan hasil perhitungan statistik deskriptif yang tampak pada Tabel 1 tersebut bahwa dari 171 data pengamatan selama periode dari tahun 2014 - 2015 menunjukan bahwa manajemen laba (EM) perusahaan yang diukur dengan menggunakan conditional revenue model yang diperkenalkan oleh Stubben (2010), memiliki nilai ratarata sebesar 0,027106, nilai maksimum sebesar 0,5527, nilai minimum sebesar -0,6912 dan nilai standar deviasi sebesar 0,1879734. Hal ini mengindikasikan bahwa data manajemen laba (EM) mempunyai sifat menyebar, yang dapat dilihat dari nilai standar deviasi yang lebih besar dari nilai rata-rata (mean). Nilai minimum manajemen laba sebesar -0,6912 terjadi di PT Multi Bintang Indonesia Tbk pada tahun 2015 yang berarti bahwa perusahaan tersebut melakukan manajemen laba dengan cara understated atau melaporkan nilai laba perusahaan dengan cara meminimalkan nilai labanya. Adapun, nilai maksimum manajemen laba sebesar 0,5527 terjadi di PT Primarindo Asia Infrastructure Tbk pada tahun 2015, hal ini berarti perusahaan tersebut melakukan manajemen laba dengan cara overstated atau melaporkan nilai laba perusahaan dengan cara memaksimalkan nilai labanya. Dari nilai tersebut juga dapat dilihat bahwa rata-rata sebesar 0,027106 perusahaan manufaktur yang menjadi sampel penelitian ini melakukan manajemen laba dengan cara overstated atau melaporkan nilai laba perusahaan dengan cara memaksimalkan nilai labanya.

Variabel kedua adalah PSAK No 50/55 (Revisi 2014) berbasis IFRS (SAK), memiliki nilai rata-rata sebesar 0,888889 , nilai maksimum sebesar 1,0000 , nilai minimum sebesar 0,0000 dan nilai standar deviasi sebesar 0,3151926. Hal ini mengindikasikan bahwa data PSAK No 50/55 (Revisi 2014) berbasis IFRS mempunyai sifat mengumpul, yang dapat dilihat dari nilai standar deviasi yang lebih kecil dari nilai rata-rata (mean). Dari nilai tersebut juga dapat dilihat bahwa rata-rata perusahaan yang menjadi sampel penelitian ini sudah menerapkan PSAK No 50/55 (Revisi 2014) berbasis IFRS yang efektif 
per 1 Januari tahun 2015 karena mendekati nilai maksimum.

Variabel penelitian ketiga adalah kualitas audit (KA), memiliki nilai rata-rata sebesar 0,350877, nilai maksimum sebesar 1,0000, nilai minimum sebesar 0,000 dan nilai standar deviasi sebesar 0,4786462. Hal ini mengindikasikan bahwa data kualitas audit (KA) mempunyai sifat mengumpul, yang dapat dilihat dari nilai standar deviasi yang lebih kecil dari nilai rata-rata (mean). Dari nilai tersebut juga dapat dilihat bahwa rata-rata sebesar 35,0877\% perusahaan manufaktur di Indonesia yang menjadi sampel penelitian ini sudah diaudit oleh KAP BigFour. Sedangkan rata-rata 64,9123\% perusahaan manfaktur di Indonesia yang menjadi sampel penelitian ini diaudit oleh KAP yang bukan KAP Big Four.

\subsection{Uji Asumsi Klasik}

Uji normalitas pada penelitian ini menggunakan uji statistik Kolmogrov-Smirno. Jika hasil pengujian menunjukkan nilai signifikan (Asymp. Sig) lebih besar atau sama dengan 0.05 maka data terdistribusi secara normal (Ho diterima), sementara jika nilai signifikan kurang dari 0.05 maka data tidak terdistribusi normal. Berikut tabel 3 menunjukkan hasil uji normalitas menggunakan One-Sample Kolmogorov-Smirnov Test.

Tabel 2. Hasil Uji Normalitas dengan Metode Kolmogorov-Smirnov

\begin{tabular}{llc}
\hline & & Unstandardized Residual \\
\hline $\mathrm{N}$ & & 171 \\
Normal Parameters a,b & Mean & $0 \mathrm{E}-7$ \\
& Std. Deviation &, 18196931 \\
\multirow{2}{*}{ Most Extreme Differences } & Absolute &, 071 \\
& Positive &, 049 \\
& Negative &,- 071 \\
Kolmogorov-Smirnov Z & &, 926 \\
Asymp. Sig. (2-tailed) & &, 358 \\
\hline
\end{tabular}

Berdasarkan Tabel 2 dapat dilihat bahwa hasil pengujian normalitas dengan uji statistik non- parametik Kolmogorov-Smirnov, menunjukkan nilai Kolmogorov-Smirnov adalah positif 0,926 dan nilai Asymp. Sig. (2-tailed) lebih besar dari 0,05, yaitu 0,358 > 0,05 . Hal ini berarti $\mathrm{H} 0$ diterima yang berarti data residual terdistribusi normal dan model regresi layak untuk dipakai dalam penelitian ini.

Uji multikolinearitas bertujuan untuk menguji apakah dalam model regresi ditemukan adanya korelasi antar variabel bebas. Dalam model regresi yang baik seharusnya tidak terjadi korelasi antara variabel bebas. Uji multikolinearitas dilakukan dengan melihat nilai tolerance dan variance inflation factor (VIF) dari hasil analisis dengan menggunakan SPSS. Apabila nilai variance inflation factor (VIF) lebih kecil dari 10, maka dapat disimpulkan tidak terjadi multikolinearitas.

Berdasarkan Tabel 3 dapat dilihat bahwa nilai tolerance yang dimiliki oleh 
masing-masing variabel di atas 0,10 yang berarti tidak terdapat korelasi antar variabel bebas. Dan dapat dilihat pula, dari hasil perhitungan VIF, tidak ada satupun variabel independen yang memiliki nilai VIF > 10. Jadi dapat disimpulkan bahwa tidak ada multikolinearitas antar variabel independen dalam model regresi.

Tabel 3. Hasil Uji Autokorelasi

\begin{tabular}{lcc}
\hline Model & $\begin{array}{c}\text { Collinearity Statistics } \\
\text { Tolerance }\end{array}$ & VIF \\
\hline (Constant) & & \\
SAK &, 957 & 1,045 \\
KA &, 957 & 1,045 \\
\hline
\end{tabular}

Untuk mendeteksi ada tidaknya autokorelasi, dilakukan menggunakan uji DurbinWatson (DWTest). Hasil uji Durbin-Watson (DWTest) pada Tabel dibawah ini:

Tabel 4. Hasil Uji Autokorelasi

\begin{tabular}{cccccc}
\hline Model & R & R Square & $\begin{array}{c}\text { Adjusted R } \\
\text { Square }\end{array}$ & $\begin{array}{c}\text { Std. Error of } \\
\text { the Estimate }\end{array}$ & $\begin{array}{c}\text { Durbin- } \\
\text { Watson }\end{array}$ \\
\hline $\mathbf{1}$ &, $251^{\mathrm{a}}$ &, 063 &, 052 &, 1830493 & 2,049 \\
\hline
\end{tabular}

Dari Tabel 4 dapat diketahui nilai Durbin-Watson sebesar 2,049, Nilai ini kemudian dibandingkan dengan tabel Durbin-Watson (DW), a $=5 \%$ dengan jumlah sampel sebanyak 171 perusahaan dan jumlah variabel independen $(k=2)$, maka dapat dilihat pada tabel Durbin-Watson (DW) nilai du $=1.76159$ dan nilai $\mathrm{dl}=1,73808$, sehingga dapat disimpulkan 1,76159 2,049 < 4,76159. Artinya nilai DW hitung 2,049 lebih besar dari batas atas (du) 1,76159 dan kurang dari batas bawah (4 - du) 2,23841, maka dapat disimpulkan bahwa Ho diterima yang menyatakan bahwa tidak ada autokorelasi positif atau negatif dan disimpulkan bahwa tidak terdapat autokorelasi.

Uji heteroskedastisitas menggunakan uji glejser. Uji Glejser dilakukan dengan cara meregresikan antara variabel independen dengan nilai absolut residualnya. Jika nilai signifikansi antara variabel independen dengan absolut residual lebih dari 0.05 maka tidak terjadi masalah heteroskedastisitas. Tabel 5 berikut menunjukkan hasil uji glejser.

Tabel 4. Hasil Uji Glejser

\begin{tabular}{lccccc}
\hline \multirow{2}{*}{ Model } & \multicolumn{2}{c}{ Unstandardized Coefficients } & Standardized Coefficient & & \\
\cline { 2 - 4 } & B & Std. Error & Beta & T & Sig. \\
\hline Constant) &, 142 &, 030 & & 4,696 &, 000 \\
SAK &, 000 &, 030 &,- 001 &,- 017 &, 987 \\
KA &,- 013 &, 020 &,- 051 &,- 646 &, 519 \\
\hline
\end{tabular}

Model regresi dinyatakan bebas dari gejala heteroskedastisitas, adalah jika pada model regresi mempunyai nilai signifikansi (sig.) variabel independen lebih besar dari 0,05. Berdasarkan Tabel 4 dapat dilihat hasil pengujian berdasarkan uji glejser, menunjukkan nilai Signifikansi (sig.) dari masing-masing variabel independen lebih besar 
dari 0,05 . Hal ini dapat disimpulkan bahwa model regresi tidak mengandung adanya heteroskedastisitas.

\subsection{Uji Hipotesis}

Koefisien determinasi $\left(\mathrm{R}^{2}\right)$ digunakan untuk mencari kontribusi variabel bebas terhadap variabel terikat. Koefisien determinasi $\left(\mathrm{R}^{2}\right)$ digunakan untuk mencari kontribusi variabel bebas terhadap variabel terikat.

Tabel 5. Hasil Uji $\mathbf{R}^{2}$

\begin{tabular}{cccccc}
\hline Model & $\mathbf{R}$ & $\begin{array}{c}\mathbf{R} \\
\text { Square }\end{array}$ & $\begin{array}{c}\text { Adjusted } \\
\text { R Square }\end{array}$ & $\begin{array}{c}\text { Std. Error of } \\
\text { the Estimate }\end{array}$ & $\begin{array}{c}\text { Durbin- } \\
\text { Watson }\end{array}$ \\
\hline $\mathbf{1}$ &, $251^{\mathrm{a}}$ &, 063 &, 052 &, 1830493 & 2,049 \\
\hline
\end{tabular}

Hasil analisis regresi linier berganda pada Tabel 7 di atas dapat terlihat besarnya nilai adjusted $R$ square adalah sebesar 0,052 yang menunjukan bahwa sebesar 5,2\% variabel manajemen laba pada perusahaan manufaktur yang terdaftar di Bursa Efek Indonesia periode 2014 - 2015, dipengaruhi oleh kedua variabel independen yang diteliti, yaitu PSAK 50/55 (Revisi 2014) berbasis IFRS tahun 2015 (SAK) dan kualitas audit (KA)., sedangkan sisanya yaitu 94,8\% dipengaruhi oleh faktor-faktor lain yang belum diteliti dalam penelitian ini.

Uji ini digunakan untuk menentukan analisis pengaruh apakah penerapan PSAK 50/55 (Revisii 2014) berbasis IFRS (SAK) dan kualitas audit secara bersama-sama (simultan) berpengaruh terhadap praktik manajemen laba pada perusahaan manufaktur yang terdaftar di Bursa Efek Indonesia periode 2014 - 2015. Adapun hasil analisis regresi berganda simultan dapat dilihat pada Tabel 4.8 sebagai berikut:

Tabel 6. Hasil Uji Statistik F

\begin{tabular}{lccccc}
\hline Model & $\begin{array}{c}\text { Sum of } \\
\text { Squares }\end{array}$ & Df & $\begin{array}{c}\text { Mean } \\
\text { Square }\end{array}$ & F & Sig. \\
\hline Regression &, 378 & 2 &, 189 & 5,635 &, $004^{\mathrm{b}}$ \\
Residual & 5,629 & 168 &, 034 & & \\
Total & 6,007 & 170 & & & \\
\hline
\end{tabular}

Hasil pengujian dengan tingkat signifikan 5\% $(0,05)$. Jika dilihat dari nilai sig hitung adalah sebesar 0,004 artinya lebih kecil dari 0,05 maka keputusannya juga menolak H0. Sehingga, dapat disimpulkan bahwa secara simultan terdapat pengaruh penerapan PSAK 50/55 (Revisii 2014) berbasis IFRS tahun 2015 (SAK) dan kualitas audit terhadap praktik manajemen laba pada perusahaan manufaktur yang terdaftar di Bursa Efek Indonesia periode 2014-2015 atau dapat dikatakan bahwa model regresi dapat digunakan untuk memprediksi praktik manajemen laba.

Uji ini digunakan untuk menentukan analisis pengaruh apakah penerapan PSAK 50/55 (Revisi 2014) berbasis IFRS tahun 2015 (SAK) dan kualitas audit (KA) secara 
parsial berpengaruh terhadap praktik manajemen laba pada perusahaan manufaktur yang terdaftar di bursa efek Indonesia periode 2014 - 2015. Hasil pengujiannya dapat dilihat dari besarnya thitung terhadap t Tabel dengan uji 2 sisi. Dalam penelitian ini diketahui bahwa $\mathrm{n}=156$ pada tingkat signifikansi 5\%. Pada t tabel lihat tingkat kesalahan $(\mathrm{a}=0,05)$ dengan menggunakan uji 2 sisi diperoleh nilai t tabel $(156 ; 0,025)$ sebesar 1,97539. Adapun hasil t hitung dari variabel independen adalah sebagai berikut:

Tabel 7. Hasil Uji Statistik T-test

\begin{tabular}{lccccc}
\hline \multirow{2}{*}{ Model } & \multicolumn{2}{c}{ Unstandardized Coefficients } & Standardized Coefficient & & \\
\cline { 2 - 4 } & B & Std. Error & Beta & T & Sig. \\
\hline Constant) &, 155 &, 046 & & 3,363 &, 001 \\
SAK &,- 111 &, 046 &,- 186 & $-2,440$ &, 016 \\
KA &,- 083 &, 030 &,- 211 & $-2,762$ &, 006 \\
\hline
\end{tabular}

Berdasarkan hasil Tabel 7 di atas dapat dijelaskan bahwa Hipotesis pertama (H1) menyatakan bahwa PSAK 50/55 (Revisi 2014) berbasis IFRS tahun 2015 (SAK) berpengaruh terhadap praktik manajemen laba. Berdasarkan analisis data pengujian $\mathrm{H} 1$ menunjukan angka nilai signifikansi sebesar 0,016 ( $p<0,05)$, artinya menunjukan bahwa terjadi pengaruh yang signifikan. Oleh karena itu, dapat disimpulkan bahwa penerapan PSAK 50/55 (Revisi 2014) berbasis IFRS tahun 2015 berpengaruh secara signifikan terhadap praktik manajemen laba, sehingga hipotesis $\mathbf{H 1}$ diterima.

Hipotesis kedua (H2) menyatakan kualitas audit berpengaruh terhadap praktik manajemen laba. Berdasarkan analisis data pengujian $\mathrm{H} 2$ menunjukkan angka nilai signifikansi sebesar 0,006 ( $\mathrm{p}<0,05)$, artinya menunjukan bahwa terjadi pengaruh yang signifikan. Oleh karena itu, dapat disimpulkan bahwa kualitas audit berpengaruh terhadap praktik manajemen laba, sehingga hipotesis $\mathbf{H 2}$ diterima.

Berdasarkan penjelasan diatas dapat disimpulkan bahwa variabel manajemen laba (EM) dipengaruhi oleh variabel penerapan PSAK 50/55 (Revisi 2014) berbasis IFRS (SAK) dan kualitas audit (KA) dengan persamaan regresi:

$$
\text { Manajemen Laba }(\mathrm{EM})=0,155 \text { - 0,111 SAK - 0,083 KA }
$$

Penjelasan dari persamaan regresi diatas adalah:

a. Konstanta bernilai positif sebesar 0,155 berarti jika semua variabel independen dianggap konstan, maka besarnya praktik manajemen laba 0,155

b. Koefisien regresi variabel penerapan PSAK 50/55 (Revisi 2014) berbasis IFRS (SAK) bernilai negatif sebesar -0,111 menunjukan bahwa terjadi hubungan negatif antara SAK dengan praktik manajemen laba, semakin diterapkannya PSAK 50/55 (Revisi 2014) berbasis IFRS (SAK) oleh perusahaan, maka manajemen laba akan mengalami penurunan sebesar 0,111 dengan asumsi variabel independen lain nilainya tetap.

c. Koefisien regresi kualitas audit (KA) bernilai negatif sebesar 0,083 menunjukan bahwa jika perusahaan menerapkan kualitas audit, maka manajemen laba akan mengalami penurunan sebesar 0,083 dengan asumsi variabel independent lain nilainya 
tetap.

\subsection{Pengaruh penerapan PSAK 50/55 (Revisi 2014) berbasis IFRS terhadap manajemen laba}

Menurut PSAK No. 50 (revisi 2006) mengenai Penyajian dan Pengungkapan Instrumen Keuangan menyatakan bahwa jumlah kerugian dan pemulihan nilai aset keuangan yang terjadi diakui pada laporan laba rugi komprehensif. Pada setiap tanggal neraca Perusahaan mengevaluasi apakah terdapat bukti obyektif bahwa aset keuangan atau kelompok aset keuangan yang diklasifikasikan sebagai kelompok dimiliki hingga jatuh tempo, tersedia untuk dijual atau pinjaman yang diberikan dan piutang mengalami penurunan nilai.

PSAK 55 tentang pengakuan dan pengukuran instrumen keuangan salah satunya membahas tentang penurunan nilai dan tidak tertagihnya aset keuangan. Perusahaan yang melakukan pembiayaan, risiko terbesarnya adalah gagal bayar dan bila terjadi perusahaan akan membuat cadangan penurunan nilai. Cadangan penurunan nilai tergantung dari estimasi perusahaan terhadap seberapa besar gagal bayar yang terjadi, jika gagal bayar semakin besar maka cadangan kecukupan penurunan nilai akan semakin tinggi. Laporan laba rugi akan terpengaruh karena besarnya cadangan kecukupan penurunan nilai, pendapatan yang diperoleh perusahaan akan semakin kecil.

Hasil penelitian ini menunjukan bahwa variabel penerapan PSAK 50/55 (Revisi 2014) berbasis IFRS berpengaruh secara signifikan terhadap praktik manajemen laba sehingga hipotesis penelitian ini yang menyatakan bahwa penerapan PSAK 50/55 (Revisi 2014) berbasis IFRS berpengaruh signifikan negatif terhadap manajemen laba diterima.

Pengaruhnya signifikan negatif berarti semakin diterapkannya PSAK 50/55 (Revisi 2014) berbasis IFRS oleh perusahaan, maka diprediksi akan mampu menurunkan praktik manajemen laba di dalam perusahaan. Dampak penerapan PSAK 50/55 berbasis IFRS yaitu memberikan pengaruh terhadap pelaporan keuangan dan pengungkapan pada pelaporan keuangan perusahaan. Pengaruhnya pada laporan keuangan adalah perusahaan mengharuskan adanya penyajian nilai wajar (fair value), salah satu contoh instrumen keuangannya adalah piutang yang diukur pada pengakuan awal sebesar nilai wajar. Penerapan PSAK 50/55 (Revisi 2014) berbasis IFRS dapat digunakan untuk menekan atau mengurangi praktik manajemen laba karena pendapatan yang berhubungan dengan kegiatan usaha seperti pendapatan bunga, pendapatan administrasi dan asuransi tidak dapat dicatatkan sebagai pendapatan di depan. Pendapatan tersebut harus diamortisasi sesuai dengan tenor.

Hasil penelitian tersebut diatas sejalan dengan pernyataan IAI tahun 2009 dalam Narendra (2013) yang menyebutkan bahwa IFRS dapat mempersulit tindakan manajemen laba melalui penerapan fair value dan balance sheet approach. Hasil penelitian Narendra, 
(2013) menyatakan bahwa IFRS dengan pendekatan principled based-nya dianggap dapat meminimalisir tingkat manajemen laba yang dilakukan oleh manaj emen dengan pengetatan aturan dan pendekatan fair value dalam penyajian laporan keuangannya. Hasil penelitian yang dilakukan oleh Kurniawati (2014) yang meneliti tentang pengaruh adopsi IFRS terhadap manajemen laba pada perusahaan manufaktur yang terdaftar di Bursa Efek Indonesia menemukan bahwa adanya pengaruh adopsi IFRS terhadap manajemen laba, dimana manajemen laba menjadi lebih rendah setelah adopsi IFRS. Penelitian Qomariah dan Marsono (2013), Ichi dan Fikrotusshohah (2014), menyimpulkan bahwa penerapan IFRS menunjukkan pengaruh negatif yang signifikan terhadap manajemen laba, hal ini berarti pada saat adanya konvergensi IFRS akan mempengaruhi tindakan manajemen untuk meminimalisir tindakan memanipulasi yang bertujuan untuk kepentingan pribadinya. Demikian pula Rohaeni dan Aryati (2012) juga menemukan bahwa adopsi IFRS berpengaruh negatif terhadap income smoothing. Ewert dan Wagenhof (2005) dalam Eka Purnamasari (2014) dan Zeghal dkk (2011), Barth dkk (2008), Daske dkk (2008) dalam Papeke (2015) menyatakan bahwa adopsi IFRS dapat menurunkan level manajemen laba.

\subsection{Pengaruh kualitas audit terhadap manajemen laba}

Dalam penelitian ini pengklasifikasian ukuran Kantor Akuntan Publik dilakukan dengan membedakan ukuran Kantor Akuntan Publik menjadi Kantor Akuntan Publik besar yaitu big four dan Kantor Akuntan Publik kecil atau non-big four. Secara umum pembedaan ini didasarkan pada jumlah klien yang dilayani oleh suatu KAP, jumlah rekan atau anggota yang bergabung serta total pendapatan yang diperoleh dalam satu periode. Hasil penelitian ini menunjukan bahwa variabel kualitas audit berpengaruh signifikan negatif terhadap praktik manajemen laba, sehingga hipotesis penelitian yang menyatakan bahwa kualitas audit berpengaruh signifikan negatif terhadap praktik manajemen laba diterima.

Pengujian hipotesis variabel ukuran KAP diperoleh signifikansi sebesar 0,083. Dengan nilai signifikansi di bawah 0,05 berarti bahwa ukuran KAP memiliki pengaruh terhadap manajemen laba. Arah koefisien negatif menunjukkan semakin besar ukuran KAP (Big four) maka semakin kecil manajemen laba yang dilakukan oleh perusahaan. Auditor yang termasuk Big four lebih kompeten dibanding auditor non big four, sehingga ia memiliki pengetahuan lebih banyak tentang cara mendeteksi dan memanipulasi laporan keuangan maupun melakukan tindakan manajemen laba. Penelitian ini konsisten dengan penelitian yang dilakukan Inaam dkk (2012) yang menyatakan auditor big four lebih memiliki kualitas yang tinggi dalam meminimalkan praktik manajemen laba dibandingkan auditor non big four.

Dari data masing-masing perusahaan dapat dilihat bahwa semakin besar ukuran KAP dalam suatu perusahaan, maka akan semakin mengurangi manajemen laba. KAP Big Four akan bekerja secara professional untuk menghasilkan kinerja yang baik dalam 
menjaga reputasinya. Kualitas audit yang dilakukan oleh KAP yang reputasinya baik akan lebih menjamin tentang akuntabilitas kinerja keuangan perusahaan yang diauditnya sehingga dapat menekan praktek manajemen laba. Hal ini bisa dilihat pada PT. Multi Bintang Indonesia Tbk pada tahun 2015, dimana tingkat manajemen laba tersebut sebesar $-0,6912$.

Sebaliknya perusahaan yang diaudit oleh KAP yang Non Big Four, cenderung praktek manajememen labanya lebih tinggi karena auditor KAP Big Four kurang bisa bekerja secara professional untuk menghasilkan kinerja yang baik serta kurang terjaminnya akuntabilitas kinerja keuangan perusahaan yang diauditnya. Hal ini dapat dilihat pada PT Primarindo Asia Infrastructure Tbk pada tahun 2015, dimana tingkat manajemen laba tersebut sebesar 0,5527. Hal ini menunjukkan bahwa PT. Primarindo Asia Infra Structure yang diaudit oleh KAP Non Big Four memiliki kecenderungan melakukan praktek manajemen laba sangat tinggi sekali.

Dengan menaikkan laba, para manajer berharap investor akan meresponsnya dengan positif, sehingga harga saham perusahaan meningkat. Jika kompensasi para manajer didasarkan pada ukuran kinerja keuangan dan kinerja pasar, para manajer akan berusaha untuk menunjukkan kinerja yang prima dengan motif pencapaian kompensasi tersebut. Prinsipal akan menaikkan kompensasi dan mempertahankan mereka untuk memimpin perusahaan. Tingkat kepercayaan kreditur akan meningkat dan kemudahan pinjaman dana akan meningkat pula. Begitu pula dengan pelanggan, tingkat kepercayaan dan market share diperkirakan dapat berkembang karena perusahaan dinilai memiliki reputasi baik. Singkatnya, dengan menaikkan laba para manajer dapat meningkatkan keuntungan baik itu keuntungan secara individu maupun kolektif.

Namun demikian, dampak negatif penurunan kualitas laporan keuangan akibat dari kebijakan manajemen laba adalah laporan keuangan menjadi tidak sesuai dengan matching principle karena biaya yang seharusnya terjadi tahun ini tetapi ditunda menjadi biaya tahun depan. Hal ini menjadi tidak smooth, dan kalau dilakukan secara terus menerus dan dalam jangka waktu yang panjang akan mengakibat perusahaan menjadi colaps seperti yang terjadi pada kasus Enron.

\section{SIMPULAN DAN SARAN}

Penelitian ini bertujuan untuk menguji pengaruh penerapan PSAK 50/55 (Revisi 2014) berbasis IFRS dan kualitas audit terhadap praktik manajemen laba pada perusahaan manufaktur yang terdaftar di Bursa Efek Indonesia periode 2014 - 2015. Kualitas audit pada penelitian ini ditunjukkan dengan ukuran KAP. Berdasarkan hasil analisis yang telah dilakukan dengan menggunakan pengujian regresi linier berganda, maka kesimpulan yang dapat diperoleh dari penelitian ini adalah sebagai berikut.

Penerapan PSAK 50/55 (Revisi 2014) berbasis IFRS terdapat pengaruh negatif dan signifikan terhadap praktik manajemen laba. Hal ini berarti bahwa Penerapan PSAK 50/55 
(Revisi 2014) berbasis IFRS, diprediksi akan mampu menurunkan praktik manajemen laba di dalam perusahaan. Apabila perusahaan menerapan PSAK 50/55 (Revisi 2014) berbasis IFRS, maka laporan keuangan akan menjadi lebih berkualitas tinggi, dapat dipahami dan dapat diterima secara global sehingga akan terjadi kontrol yang kuat atas laporan yang dihasilkan dan akan menurunkan keinginan manajemen perusahan untuk melakukan praktik manajemen laba. Jika perusahaan tidak menerapkannya, maka kemungkinan akan semakin tinggi motivasi manajer untuk memanipulasi laporan keuangan yang seringkali hasilnya tidak sesuai dengan keadaan perusahaan, sehingga merugikan stakeholder.

Kualitas Audit, terbukti terdapat pengaruh negatif dan signifikan terhadap praktik manajemen laba. Hal ini berarti bahwa, semakin baik kualitas audit yang ditunjukkan oleh KAP Big Four di dalam suatu perusahaan manufaktur maka kemungkinan untuk melakukan manajemen laba akan semakin rendah. Hal ini disebabkan adanya hubungan yang positif antara ukuran KAP dan kualitas audit, di mana tingkat reputasi perusahaan merupakan salah satu penyebab. KAP Big Four mempunyai insentif lebih besar untuk mengaudit lebih akurat karena mereka memiliki lebih banyak hubungan spesifik dengan klien yang akan hilang jika mereka memberikan laporan yang tidak akurat.

Selain itu, adanya kekayaan atau aset yang lebih besar yang dimiliki KAP Big Four juga diindikasi telah menjadi inti kekuatan KAP Big Four untuk menghasilkan laporan audit yang lebih akurat dibandingkan dengan auditor dengan kekayaan yang lebih sedikit. Kekuatan KAP Big Four untuk menghasilkan audit yang berkualitas juga diperkuat adanya sumber daya manusia yang lebih berkualitas dibandingkan dengan KAP kecil. KAP Big Four lebih mempertimbangkan kredibilitasnya saat menerima klien yang memiliki resiko tinggi. Sedangkan KAP kecil lebih berani menerima klien yang memiliki risiko yang lebih tinggi dikarenakan adanya motif hubungan jangka panjang.

Berdasarkan keterbatasan yang telah diuraikan, maka perlu menjadi bahan pengembangan pada penelitian sejenis berikutnya. Untuk penelitian selanjutnya diharapkan dapat mengembangkan penelitian ini khususnya pengaruh penerapan PSAK 50/55 (Revisi 2014) berbasis IFRS yaitu pra PSAK 50/55 (Revisi 2014) berbasis IFRS dan pasca penerapan PSAK 50/55 (Revisi 2014) berbasis IFRS terhadap manajemen laba. Sehingga penelitian tentang pengaruh penerapan PSAK 50/55 (Revisi 2014) berbasis IFRS pada pelaporan keuangan di Indonesia juga lebih nyata dan jelas apakah berpengaruh pada manajemen laba dengan menggunakan pembanding pra penerapan PSAK 50/55 (Revisi 2014) berbasis IFRS dengan pasca penerapan PSAK 50/55 (Revisi 2014) berbasis IFRS.

Agar penelitian selanjutnya diharapkan lebih memperluas sampel penelitian perusahaan, sebaiknya tidak hanya dari perusahaan manufaktur saja tetapi dari jenis industri lainnya yang terdaftar di Bursa Efek Indonesia. Sehingga kesimpulan untuk penelitian selanjutnya dapat lebih akurat dan menggambarkan ada tidaknya perbedaan, jika menggunakan sampel seluruh perusahaan yang terdaftar di Bursa Efek Indonesia, 
serta untuk mengukur manajemen laba peneliti selanjutnya dapat mengunakan model lainnya seperti revenue model.

Karena nilai adjusted $R$ square terlalu kecil sebesar 0,052, maka penelitian selanjutnya perlu mengidentifikasi kualitas audit yang lain untuk mengetahui sejauh mana pengaruh kualitas audit terhadap manajemen laba, dengan menambah variabel independen lain yang diduga berpengaruh terhadap manajemen laba, misalnya auditor spesialis industri, masa penugasan auditor dan independensi auditor dalam opini going concern.

\section{DAFTAR PUSTAKA}

Chen, H., Tang, Q., Jiang, Y., \& Lin, Z. (2010). The Role of International Financial Reporting Standards in Accounting Quality: Evidence from the European Union. Journal of International Financial Management \& Accounting, 21(3), 220-278.

Eka Purnamasari, Y. (2010). Pengaruh Adopsi IFRS, Leverage Dan Ukuran Perusahaan Terhadap Manajemen Laba. Jurnal Ilmu \& Riset Akuntansi, 3(12), 1-22.

Ferdiansyah, V. (2014). Pengaruh Kualitas Audit, Kompensasi Bonus, Struktur Kepemilikan, dan Ukuran Perusahaan Terhadap Manajemen Laba, Jurnal TEKUN, 5(2), 230-249.

Ghozali, I. (2013). Aplikasi Analisis Multivariate dengan Program IBM SPSS 21 (Ed. 7). Semarang: Badan Penerbit Universitas Diponegoro.

Guna, W. I. \& Herawaty, A. (2010). Pengaruh Mekanisme Good Corporate Governance, Independensi Auditor, Kualitas Audit dan Faktor Lainnya Terhadap Manajemen Laba. Jurnal Bisnis Dan Akuntansi, 12(1), 53-68.

Handayani, Y. P. (2014). Analisis Perbedaan Manajemen Laba Sebelum Dan Sesudah Penerapan Standar Akuntansi Keuangan (Konvergensi IFRS) (Studi Empiris Pada Perusahaan Manufaktur Yang Terdaftar Di BEI) (Artikel Skripsi), Universitas Negeri Padang, Indonesia.

Handono, S. W., Candrasari, R. \& Natalia, I. (2013). Akuntansi Pengantar 1: Sistem Penghasil Informasi Keuangan Adaptasi IFRS. Yogyakarta: AB PUBLISHERYogyakarta.

Icih \& Fikrotusshohah, I. (2014). Analisis Kualitas Informasi Akuntansi Sebelum Dan Sesudah Adopsi Penuh International Financial Reporting Standard (IFRS) (Studi Kasus Pada Perusahaan Manufaktur Yang Terdaftar Di Bursa Efek Indonesia Periode 2010-2013), Proceeding SNEB. Subang: STIE Sutaatmadja. 
Kabo, M. (2011). Manajemen Keuangan Teori Sinyal. Diakses dari http://ekonomi.kabo.biz/2011/07/teori-sinyal.html.

Kurniawati, L. (2014). Pengaruh Adopsi IFRS Terhadap Manajemen Laba Pada Perusahaan Manufaktur Yang Terdaftar Di Bursa Efek Indonesia (Tesis yang tidak dipublikasikan), Universitas Sebelas Maret, Indonesia.

Martani, D. (2016). Slide PSAK Efektif 2015 (Revisi): Overview Implementation IFRS (Penerapan PSAK Berbasis IFRS Efektif Sampai Dengan 2015). Diakses dari https://staff.blog.ui.ac.id/martani/pendidikan/slide-psak/.

Narendra, A. (2013). Pengaruh Pengadopsian International Financial Reporting Standards (IFRS) Terhadap Manajemen Laba (Studi Empiris Pada Perusahaan Manufaktur Yang Terdaftar Di Bursa Efek Indonesia Pada Tahun 2011-2012) (Skripsi yang tidak dipublikasikan), Universitas Diponegoro, Indonesia.

Nur'aini, M., \& Raharja, S. (2012). Studi Perbandingan Model Revenue Dan Model Accrual Dalam Mendeteksi Manajemen Laba (Studi Pada Perusahaan Manufaktur yang Terdaftar di Bursa Efek Indonesia Pada Tahun 2006-2010). Diponegoro Journal of Accounting. 1(1), 1-13.

Nuraini, H. I. (2014). Kualitas Informasi Akuntansi Sebelum Dan Sesudah Konvergensi IFRS Di Indonesia (Tesis yang tidak dipublikasikan), Universitas Gadjah Mada, Indonesia.

Papeke, I. B. (2015). Analisis Terhadap Hubungan Antara Konvergensi International Financial Reporting Standar (IFRS), Manajemen Laba Dan Kualitas Audit (Skripsi yang tidak dipublikasikan), Universitas Diponegoro, Indonesia.

Priyatno, D. (2008). 5 Jam Belajar Olah Data Dengan SPSS 17. Yogyakarta: Andi Offset.

Samekto, D. G. (2013). Pengaruh Pengadopsian International Financial Reporting Standard Terhadap Catatan Auditor, (Skripsi yang tidak dipublikasikan), Universitas Diponegoro, Indonesia.

Stubben, S. R. (2010). Discretionary Revenue as a Measure of Earnings Management. The Accounting Review, 85(2), 695-717.

Suwardjono. (2014). Teori Akuntansi: Perekayasaan Pelaporan Keuangan. Yogyakarta: BPFE- Yogyakarta.

Watts, R. L. \& Zimmerman, J. L. (1990). Positive Accounting Theory: A TenYear Perspective. The Accounting Review, 65(1), 131-156 